\title{
The great sphinx at Giza: the immortal witness of interconnections between east and west
}

Keywords: touristic sites, egypt, legendary pyramids, great sphinx

\section{Opinion}

The Giza Plateau is among the most important archaeological and touristic sites in Egypt and the world. The unique fame of this World Heritage Site comes from the presence of the legendary Pyramids of the Fourth Dynasty, the temples and cemeteries and of course, the Great Sphinx. Although the necropolis of Giza was used throughout the ancient Egyptian period, the Old Kingdom cemetery was the most appreciated by the ancient Egyptians themselves. The Great Sphinx is located at the eastern edge of the Giza Plateau, which goes back to the Eocene Period. The Sphinx is carved into the rock to the left of the beginning of the causeway of the Pyramid complex of King Khafre, the builder of the Second Pyramid at Giza. It was a new and unique element in the pyramid complex of Khafre, never to be repeated and was an essential part of it.

The statue is around 22 meters in height and 75 meters in length. It is probably the largest man-made statue sculpted from a single block of stone in the world. In the majority of opinions, the Great Sphinx dates to the reign of King Khafre. It has a human head and a lion's body to express the intellectuality of human beings and the strength of the lion, an animal which was associated with the solar religion in the Old Kingdom. The statue faces the rising sun. The human head of the statue represents king Khafre wearing the nemes-headdress topped by the uraeus on the forehead of the king. The nose of the statue is now broken and the beard is gone. However, some pieces of the beard are currently housed in the Egyptian Museum in Cairo and in the British Museum in London. In front and to the right of the Sphinx are located the Valley Temple of King Khafre and the Sphinx Temple, which are similar in architectural design.

During the New Kingdom, the Great Sphinx was called "Horemakhet" and "Horoun" or "Horna" or "Hol" by the Canaanites. The classical writers called the statue the Sphinx, probably derived from the ancient Egyptian word "Ssp anx" meaning "living image" of the sun god. The Arabic name "Abu Al-Hol" probably came from the expression "pr-Hwl" meaning "House of Hol" or "pw-Hwl" meaning "Place of Hol". As a result, the current Arabic name is not related to the literal meaning of the ancient Egyptian one. Many famous individuals have visited the Great Sphinx from ancient Egyptian to modern times. This fascinating statue has always attracted the minds and imagination of its visitors from all periods. In order to pay homage to the statue in ancient Egypt, many votive stelae by royal and non-royal individuals were placed around the Great Sphinx, the most famous being the stelae of Amenhotep II and the well-known "Dream Stela" of Thutmose IV.

Amenhotep II built the Temple of Hormakhis to the north-east of the Sphinx. And Thutmose IV built an enclosure wall around the Sphinx to stop the sand from hiding the statue. When the famous Greek historian Herodotus visited the Giza Pyramids in the middle of the fifth century BC, he did not mention the Great Sphinx because
Volume 2 Issue 3 - 2017

\author{
Hussein Bassir \\ Director of the Antiquities Museum, Bibliotheca Alexandrina, \\ Egypt
}

Correspondence: Hussein Bassir, Director of the Antiquities Museum, Bibliotheca Alexandrina, Egypt, Email husseinbassir200I@yahoo.com

Received: November 16, 2017 | Published: December 28, 2017

the statue was probably covered by sand at that time. Afterwards, the Arab writers described only the Pyramids and the head of the Great Sphinx, meaning that the statue was covered up to the neck with sand by that time. When Napoleon Bonaparte came to Egypt in 1798, the Great Sphinx was also partially covered by sand. The French scientists who accompanied his expedition drew a map of the Giza Plateau and cleaned the sand from around the head and neck of the Sphinx.

The Great Sphinx is composed of rock from three geological layers. The strongest one makes up the head and lower portion of the statue, while the weakest ones make up the neck and chest of it. The Sphinx has been the object of many restoration operations over time. The first of these was carried out by Thutmose IV when he removed the sand around the statue, built a mudbrick enclosure wall around the Sphinx and its buildings and restored some of the deteriorated parts of the statue. As a result, the god Hormakhis made him king of Egypt, according to his famous Dream Stela. In the Roman period, the statue was restored during the reigns of the emperors Marcus Aurelius and Septimus Severus. Later, the Egyptologists Caviglia, Mariette and Maspero all tried to remove the sand around the Sphinx, but their efforts were not complete. Baraize was the first to remove the sand from around the statue and also restore the head of the Sphinx, including the neck and some parts of the body, but unfortunately he used cement to do so.

In World War II, bags of sand were placed underneath the chin of the statue and in front of its chest to protect it from air strikes. In the 1980s, some parts of the statue fell off and as a result the then Egyptian Antiquities Organization held a conference in order to agree on the removal of the older outer casing stones that had been added to the statue during previous restoration projects and their replacement with new stone from the Torah quarries. Several other conferences, meetings and projects to restore the Great Sphinx followed. Most recently, the Ministry of Antiquities in cooperation with USAID has started a project to clear the ground water underneath and around the Great Sphinx because of the high water table in the area. The underground water had been seeping across the whole area, turning it almost into an artificial lake, especially the archaeological harbor east of the Sphinx Temple and the Valley Temple of Khafre.

The project was contemporary with the covering of the AlMansouriyah Canal about 500 meters to the east of the Great Sphinx. 
An Egyptian construction company completed the project under the supervision of the Giza Pyramids Area. The company installed meters to record the underwater level in the area and set up a network of wells to transfer water away from the Great Sphinx to the Al-Mansouriyah Canal. All these efforts have succeeded in keeping the Great Sphinx in outstanding condition and safe for enjoyment by future generations. The Great Sphinx has seen a number of restoration efforts over the centuries by great kings and visitors to Egypt. If rulers like Thutmose IV are to be believed, it must feel tremendous appreciation for all the preservation efforts it has received from friends around the world, but especially those in Egypt and the United States. It is our hope that through these efforts the Great Sphinx will continue to be an eternal symbol of Egypt, appreciated for millennia as an immortal witness to interconnections between the eastern and western worlds.

\section{Acknowledgements}

None.

\section{Conflict of interest}

Author declares that there is no conflict of interest. 